\title{
Self-Perceived Discrimination in LGBT Population in Oral Health Services. Medellín, Colombia: A Qualitative Approach
}

\author{
Santiago Alzate-Urrea ${ }^{1}$, Andrés A. Agudelo-Suárez ${ }^{1}$, James Y. Monsalve-Orrego ${ }^{1}$, Flor E. Londoño-Candanoza ${ }^{1}$, \\ Geidy del C. Chinome-Flórez ${ }^{1}$, Aida L. Julio-Pérez ${ }^{1}$, Luisa F. Arias-Durango ${ }^{1}$ \& Karen M. Pérez-Torres ${ }^{1}$ \\ ${ }^{1}$ Faculty of Dentistry, University of Antioquia, Medellín, Colombia \\ Correspondence: Santiago Alzate-Urrea, Faculty of Dentistry, University of Antioquia, U de A. Calle 70 No. \\ 52-21, Medellín, Colombia. Tel: 57-4219-6741. Fax: 57-4219-6700. E-mail: santiagoalzatte@gmail.com
}

Received: February 3, $2016 \quad$ Accepted: April 2, $2016 \quad$ Online Published: April 29, 2016

doi:10.5539/gjhs.v8n12p152 URL: http://dx.doi.org/10.5539/gjhs.v8n12p152

\begin{abstract}
Introduction: We aim to understand the perception about discrimination within the LGBT population when accessing oral health services, from their perspective as well as that of the oral health professional.

Methods: A qualitative study from a phenomenological perspective was conducted by means of 37 in-depth interwiews (19 in health service providers and 18 in LGBT members). The script used in the interview included questions related to discrimination in social spaces, quality of life and its relationship with health, access to general and oral health care and proposals and strategies. Verbatim was transcripted and narrative content analysis was carried out for identifying meaning codes and after grouped through emergent categories. Atlas. Ti 6.0 software was used.

Results: Five categories within the participants' discourses were identified: (1) Characteristics of LGBT population: This is a heterogeneous group (physical, social and cultural); (2) Quality of life (QOL), health related quality of life (HRQOL) and oral health related quality of life (OHRQOL): QOL is defined as the ability to enjoy opportunities in the human life process under equity conditions; HRQOL is related to an adequate access to health services, and OHRQOL as the appropriate state of the structures of the stomatognathic system; (3) Discrimination as a concept and experiences: People conceived discrimination as the act pejorative to someone because of a particular situation. Participants identified some types of discrimination in social spaces; (4) Accessibility to health services: Participants related individual and structural barriers when accessing to public health services; (5) Proposals and strategies: Interviewers suggested some educative strategies and social policies to reduce the endogenous and exogenous discrimination.
\end{abstract}

Conclusions: The LGBT population is vulnerable to perceive experiences of discrimination and this situation causes a negative impact on their quality of life.

Keywords: social discrimination, gender identity, homophobia, LGBT population, quality of life, qualitative research

\section{Introduction}

Discrimination is an important social fact to public health. Several international organizations such as the World Health Organization (WHO) have considered discrimination as a determinant of health that impacts on social inequalities (World Health Organisation (WHO), 2007). This acknowledgement is an important step in this field of research in terms of enquiring about the way that discrimination affects the health of the population. The consequences of discrimination in health conditions are associated with worse levels of self perceived health and chronic diseases (Gee, Spencer, Chen, \& Takeuchi, 2007; Larson, Gillies, Howard, \& Coffin, 2007; Pascoe \& Smart Richman, 2009), mental health problems (Bhui et al., 2005; Gee, Ryan, Laflamme, \& Holt, 2006); as well as a factor that has conditioned access and use of primary and specialized health care (Lauderdale, Wen, Jacobs, \& Kandula, 2006). Discrimination is a determinant of different aspects of every-day life including social, work, academic and family spheres and it precludes the comprehensive development of the people affected.

Social epidemiology, in the last decades, has explored the consequences of discrimination in different social aspects (Krieger, 2001; Krieger, Rowley, Herman, Avery, \& Phillips, 1993), and it is defined as "the process by which a member, or members, of a socially defined group is, or are, treated differently (especially unfairly) 
because of his/her/their membership of that group" (Krieger, 2001). Most social groups could be categorized as in a special situation of vulnerability depending on their place in the social structure, its position in the hierarchy of power (family, community, social and political), and the characteristics of the social context and culture, among other causes. Literature mainly reflects that most vulnerable groups to suffer discrimination are women (Ronai, Zsembik, \& Feagin, 2014), ethnic minorities (Paradies, 2006), the elderly or children (Pachter \& Coll, 2009), people with disability (Quinn, Degener, \& Bruce, 2002), homosexual and lesbians (Barrientos, Silva, Catalan, Gomez, \& Longueira, 2010), among others.

In that sense, the LGBT population (lesbian, gay, bisexual, transgender) has fought for many years to have the same rights as the heterosexual community. These benefits would allow them to have a better quality of life and access fundamental rights as: marriage, adoption, health services, access to common goods, among others (Keck, 2009; Martel, 2014). In the case of Colombia, the situation has not been different, hence several lawsuits and tutelas (term in Spanish, it refers to legal actions) for the protection of the rights of the citizens have been originated (Quijano \& Albarracín, 2009).

LGBT population particularly has been subject of studies related with perceived discrimination and situations of stress, depression, suicide attempts or poor mental health (Burgess, Lee, Tran, \& van Ryn, 2008; Mays \& Cochran, 2001; Mustanski, Garofalo, \& Emerson, 2010). Furthermore, potential barriers to health services access have been identified which involve health professionals and the system itself (Johnson, Mimiaga, \& Bradford, 2008; Kass, Faden, Fox, \& Dudley, 1992). Although there are studies on general and specialized health services discrimination to LGBT (Kass et al., 1992), research related with oral health services and the attitude towards these grous is still lacking (Campo, Díaz, \& Herazo, 2008).

This research aims at providing information to the scientific community regarding factors that cause feelings of discrimination within the LGBT when accessing oral health services, which ought to generate policies and inclusive strategies for this population as subject of rights and possibilities of human and social development. Furthermore, it aims at bringing professionals closer to this situation hence contributing with more human oral health services provision. In this sense, qualitative research has had great impact on public health and dentistry since it allows the acknowledgement of experiences and percepcions of individuals directly involved, in accordance with their social context.

Accordingly, the objective of this study is to understand the perception about discrimination within the LGBT population when accessing oral health services, from their perspective as well as that of the oral health professional.

\section{Methods}

\subsection{Design and Setting}

A qualitative study from a phenomenological perspective was developed in Medellín and its Metropolitan Area. In-depth interviews was the source of information. This approach allowed the acknowledgement of individual experiences and perceptions about a specific phenomenon by trascending the description of the social context (Cohen et al., 1994). Also, this research assumes the concept of perception from an anthropological perspective which involves a process of symbolic elaboration from the experiences that allow the attribution of characteristics of a social fact, considering culture and ideology, by means of which the individual gives different meanings to its reality (Melgarejo, 1994).

\subsection{Participants}

Participants in this study were, on the one hand, members of LGBT population, selected by theoretical sampling and contacted through Non-Governmental Organizations (NGOs) and using the snowball method, allowing the participation of volunteers. On the other hand, oral health service providers from the public and private sectors also participated. Also, a psychologist and an nurse from an NGO took part to broaden the perspective of the discourse. Tables 1 and 2 describe in detail the sociodemographic characteristics of the participants.

Table 1. Description of interviewed health personnel, Medellín, Colombia ( $\mathrm{n}=19)$

\begin{tabular}{llll}
\hline Characteristics & Men & Women & All \\
\hline Age & 3 & 3 & 6 \\
$20-30$ & 5 & 8 & 13 \\
$31-60$ & & & \\
\hline
\end{tabular}




\begin{tabular}{llll}
\hline Occupation & & & 2 \\
General dentist & 2 & 0 & 11 \\
Postgraduate dentist & 6 & 5 & 4 \\
Dentistry Assistant & 0 & 4 & 1 \\
Psychologist & 0 & 1 & 1 \\
Nurse & 0 & 1 & \\
Sector & & & 9 \\
Public & 4 & 5 & 3 \\
Private & 4 & 3 & $\mathbf{1 9}$ \\
Both & 0 & 3 & $\mathbf{1 1}$ \\
All & $\mathbf{8}$ & & \\
\hline
\end{tabular}

Table 2. Description of interviewed LGBT population, Medellín, Colombia $(\mathrm{n}=18)$

\begin{tabular}{llllll}
\hline Characteristics & Lesbian & Gay & Bisexual & Transgender & All \\
\hline Age range & & 10 & 1 & & 11 \\
$18-25$ & 2 & 2 & & 2 & 6 \\
$26-35$ & & 1 & & & 1 \\
$36-45$ & & & 2 & 2 \\
Education & 1 & 10 & 1 & & 12 \\
Secondary & 1 & 3 & & & $\mathbf{1 8}$ \\
University (students) & $\mathbf{2}$ & $\mathbf{1 3}$ & $\mathbf{1}$ & $\mathbf{2}$ & $\mathbf{1 8}$ \\
Professional & & & & & \\
All & & & & & \\
\hline
\end{tabular}

\subsection{Data Collection Techniques}

Data was collected from July 2013 and August 2014. The research group used a semi-structured interview technique using several topics and questions according to the objectives of the study and the type of participants (Table 3). These topics allowed the emergence of new categories of analysis. Interviews lasted between 20 and 90 minutes, recorded and typed for later analysis. The final number of interviews was 37, defined by the saturation of the categories of analysis defined by the study. Fieldwork was complemented using observation notes describing the main characteristics found during the interviews.

Table 3. Content of the semi-structured script used in interviews with participants, Medellín, Colombia $(\mathrm{n}=37)^{*}$

\begin{tabular}{|c|c|c|}
\hline LGBT Population & Dentists & $\begin{array}{l}\text { Dental Assistants and Dental } \\
\text { Hygienists }\end{array}$ \\
\hline $\begin{array}{l}\text { - Characteristics of LGBT } \\
\text { population. }\end{array}$ & $\begin{array}{l}\text { - Characteristics of LGBT } \\
\text { population. }\end{array}$ & $\begin{array}{l}\text { - Characteristics of LGBT } \\
\text { population. }\end{array}$ \\
\hline $\begin{array}{l}\text { The general situation of this } \\
\text { population in Medellín and } \\
\text { Colombia }\end{array}$ & $\begin{array}{l}\text { The general situation of this } \\
\text { population in Medellín and } \\
\text { Colombia }\end{array}$ & $\begin{array}{l}\text { The general situation of this } \\
\text { population in Medellín and } \\
\text { Colombia }\end{array}$ \\
\hline - Definition of quality of life. & - Definition of quality of life. & - Definition of quality of life. \\
\hline $\begin{array}{l}\text { What is quality of life related with } \\
\text { health and oral health? Valuation of } \\
\text { quality of life, negative and } \\
\text { positive feelings }\end{array}$ & $\begin{array}{l}\text { What is quality of life related with } \\
\text { health and oral health? Valuation of } \\
\text { quality of life, negative and } \\
\text { positive feelings }\end{array}$ & $\begin{array}{l}\text { What is quality of life related with } \\
\text { health and oral health? Valuation of } \\
\text { quality of life, negative and } \\
\text { positive feelings }\end{array}$ \\
\hline - Definition of discrimination & - Definition of discrimination & - Definition of discrimination \\
\hline \multirow{2}{*}{$\begin{array}{l}\text { Feelings: vulnerability, } \\
\text { dependency, insecurity, loneliness, } \\
\text { self-steem, role change, use of free } \\
\text { time. }\end{array}$} & $\begin{array}{l}\text { - Experiences of discrimination in } \\
\text { social groups. }\end{array}$ & $\begin{array}{l}\text { - Experiences of discrimination by } \\
\text { dentists }\end{array}$ \\
\hline & - Discrimination against LGBT in & - Experiences of discrimination \\
\hline
\end{tabular}


- Types of discrimination (ill treatment, physical, verbal and psychological)

- Opinion of Access to health services

- Strategies and policies public and private institutions

from hygienists

- Experience of discrimination by dentists

- Opinion of Access to health services

- Strategies and policies
- Opinion of Access to health services

- Strategies and policies

*This is a general script but during the interview new questions could have arisen from participants' experiences

\subsection{Data Analysis}

A manual analysis of the interviews was initially done in order to review initial and emerging categories. Subsequently, data were segmented using the Atlas.Ti software allowing to identifying significant text fragments from the study script used.

\subsection{Ethics}

This study complied with ethical requirements at national (República de Colombia. Ministerio de Salud y Protección Social, 1993) and international levels (World Medical Association General Assembly, 2004). It is considered a minimal risk research. Oral and written informed consent was guaranteed, as was anonymity and volunteer participation. The Faculty of Dentistry at the University of Antioquia, as an academic exercise, approved this study.

\section{Results}

As shown in Figure 1, five speech categories within the participants were identified. These categories of analysis permeate between them and they are interrelated to discrimination as a social fact. Results are presented differentiating LGBT and providers, and later to show a comparative analysis. Table 4 summarizes the main characteristics found in the interviews in terms of similarities and differences in the perception of the social phenomenon.

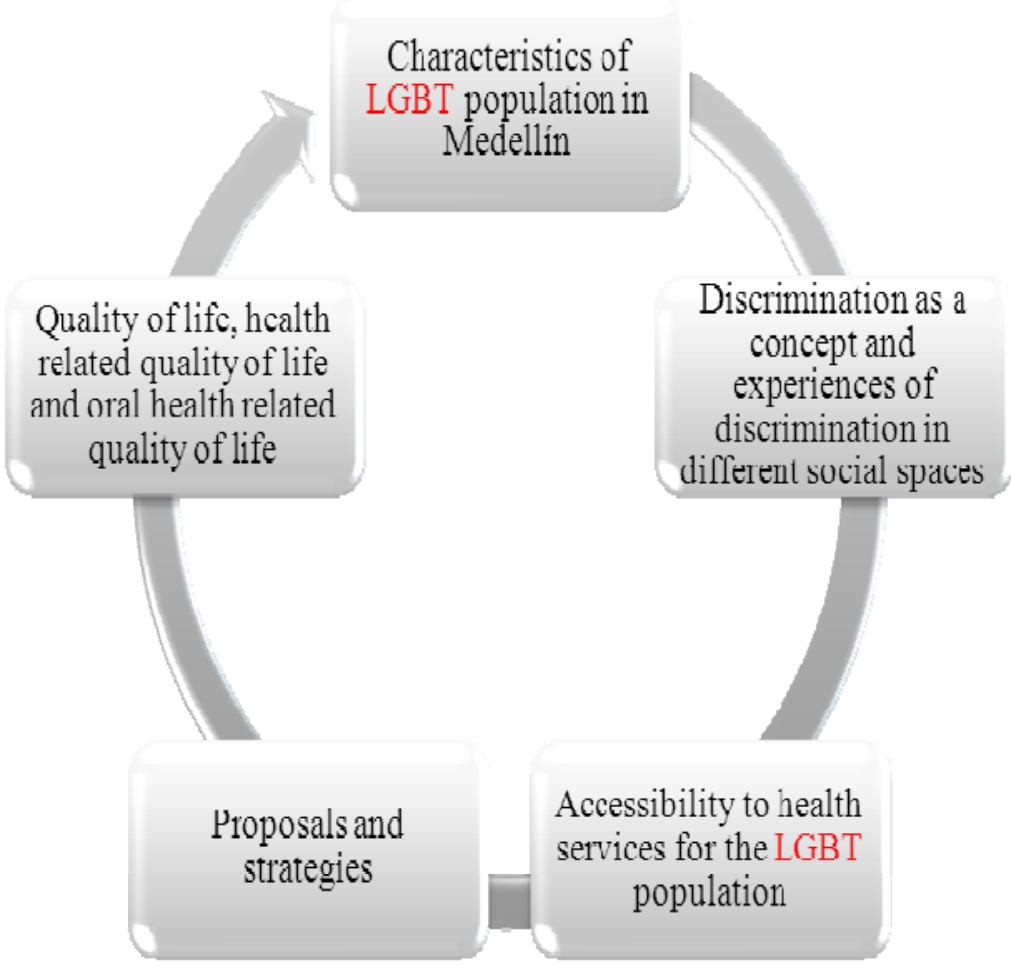

Figure 1. Conceptual categories used in the analysis of the interviews, Medellín, Colombia $(n=37)$ 
Table 4. Commonalities and differences in the answers of the LGBT population and health providers

\begin{tabular}{|c|c|c|}
\hline Category & Commonalities & Differences \\
\hline Characteristics of LGBT & $\begin{array}{l}\text { Perceived as sociodemographically } \\
\text { and culturally equality to } \\
\text { heterosexuals, though in an evident } \\
\text { state of vulnerability. }\end{array}$ & $\begin{array}{l}\text { LGBT identified endogenous } \\
\text { discrimination within the group }\end{array}$ \\
\hline \multirow{3}{*}{$\begin{array}{l}\text { Quality of life (QOL), Health } \\
\text { related Quality of life } \\
\text { (HRQOL), Oral health related } \\
\text { Quality of life related with oral } \\
\text { health (OHRQOL). }\end{array}$} & $\begin{array}{l}\text { QOL was identified as Access to } \\
\text { goods and services that allow the } \\
\text { enjoyment of life. }\end{array}$ & \multirow{3}{*}{$\begin{array}{l}\text { LGBT mentioned that QOL is related } \\
\text { also with respect for the human } \\
\text { being. } \\
\text { OHRQOL is determined to a good } \\
\text { extent by self care }\end{array}$} \\
\hline & $\begin{array}{l}\text { HRQOL was defined as an adequate } \\
\text { access to health services }\end{array}$ & \\
\hline & $\begin{array}{l}\text { OHRQOL was adopted as the } \\
\text { adequate provision of health services }\end{array}$ & \\
\hline Discrimination as a concept & $\begin{array}{l}\text { Both groups agreed on that } \\
\text { discrimination relates to a degrading } \\
\text { treatment against a person or group } \\
\text { with specific characteristics }\end{array}$ & No differences found \\
\hline $\begin{array}{l}\text { Access of LGBT to health } \\
\text { services }\end{array}$ & $\begin{array}{l}\text { Structural flaws in the health system } \\
\text { which negatively impact on its } \\
\text { provision (funding, type of insurance, } \\
\text { cost of services) }\end{array}$ & $\begin{array}{l}\text { While providers identified } \\
\text { discriminatory attitudes by the staff } \\
\text { which interferes with an adequate } \\
\text { service, LGBT did not perceive } \\
\text { them. }\end{array}$ \\
\hline Proposals and strategies & $\begin{array}{l}\text { Proposals and strategies based on } \\
\text { education. }\end{array}$ & $\begin{array}{l}\text { While providers addressed } \\
\text { educational strategies to staff, LGBT } \\
\text { mentioned they should benefit the } \\
\text { whole of the population from an } \\
\text { early age to reduce discrimination. }\end{array}$ \\
\hline
\end{tabular}

\subsection{Health Service Providers}

\subsubsection{Characteristics of LGBT Population}

When requesting a characterization of LGBT in the opinion of health service providers a homogeneous construct was identified. They expressed not finding a difference as compared with heterosexuals in terms of demographic, social or cultural characteristics. There are LGBT in all social, racial or professional groups. The difference relates mainly to sexual orientation. It is important to highlight that they comment on being aware of the political and social situation faced when promoting equal rights.

"It is just that in that population you find everything. It is like any other. There are rich, poor, professionals, ignorant... I mean it is a group like any other where you find social classes. There is no difference in that sense..." [Interview 9, Dentist (man)]

“...I believe that, taking sexual orientation aside, we are all human beings, right. We all have needs, fall ill, cry, and fell happy... I simply believe it is society that has given them a connotation of being different. Differences in likes or sexual orientation do not make us from another planet of race" [Interview 13, Dentist (man)]

3.1.2 Quality of Life (QOL), Health Related Quality of Life (HRQOL), Oral Health Related Quality of Life (OHRQOL)

Providers conceptualized QOL as the right to access goods and services to ensure a good style and way of life, meeting needs such as housing, food, education, and recreation.

“...I think there has to be some basic issues or minimum compliance of welfare in society which refer to quality of life such as health, education, and access to various goods and services of social protection. That means quality of life" [Interview 21, Dentist (woman)]

When relating HRQOL, participants identified basic elements present in good health services (accessibility, universality, integrality, efficiency, efficacy and opportunity) in the human vital process and are qualified as "vital" for normal human development.

"Good quality of life in health? To have easy access to basic health services, having the right answer at the time of a pain or illness of any kind, to have access to information useful to improve some situation that is affecting 
me at some point in my normal life" [Interview 6, Dentist (man)]

Now, OHRQOL was defined as the access to oral health services in all levels from the onset of life accordingly to each individual's and community's needs.

“...Having access to prevention from the onset of life, right. Having all basic tools for oral health care and accessing different levels of attention in dentistry, depending on the person's needs" [Interview 7, Specialist Dentist (woman)]

\subsubsection{Discrimination as a Concept and Experiences}

Providers understand discrimination as differentiated and derogatory treatment against someone in a specific condition or with particular characteristics, and outside conventional behavior in society. This affects directly the quality of life and personal and social growth. Participants identified different types of discrimination based on the person it affects: women, children, elderly, LGBT, among others; and its form: verbal, physical, behavioral, psychological.

Discrimination against providers was not identified. However, they do relate discriminatory behaviors against LGBT, in particular transgressions against transsexuals in public places.

"Discriminating is like isolating people, picking them out. You, not you, you can't you are not capable, and taking them out" [Interview 16, Dental Hygienist (woman)]

"I have witnessed molestation against people here and on the street. People on the street, travesty, eh! Transsexual who are physically attacked on the street because of their sexual orientation or by taxi drivers. This is a macho society, very traditional, little progressive in many aspects of social life. There have been important steps taken in the world that are yet to happen here. In those scenarios I have seen physical and psychological abuse" [Interview 1, Dentist (man)]

\subsubsection{LGBT Population Access to Health Services}

When interviewing health service providers regarding access by LGBT population, they identified barriers as: rush attention, excessive biosafety measures, whisper, indirect mocking and service denial. It is important to highlight that these acts impact directly on the adequate service as well as the quality of life also in health and oral health of LGBT population. These actions occur mostly in public hospitals and to transsexual people whose appearance is most impressive to staff.

"I noticed people are too aware to LGBT only if there is a possibility of HIV or STD, and then people take extra protective measures if a homosexual person comes to consult" [Interview 8, Dentist (women)]

"I did get to see a gay person with HIV in the emergency room. I know protection is very important but they overreacted then. I even think the patient felt uncomfortable because he was not terminal to be treated in that manner: 20 gloves, 3 masks, covered the chair, and the instrumental was sterilized like 20 times... they overreacted. I considered it was enough to wash it and sterilize it but the instruments were isolated for a long time just because" [Interview 18, Dental assistant (woman)]

\subsubsection{Proposals and Strategies}

Health service providers made proposals and strategies to reduce discrimination against LGBT, based on education of staff and the vulnerable population. It would take place in governmental entities, and technical and higher education institutions, and cover topics as diversity, human gender and comprehensive attention and care of the patient as a person.

"I mean, educating on being human beings and the possibilities of finding people of different race or sexual orientation or religion, is a matter of tolerance" [Interview 2, Dentist (man)]

"...to me it has to be something more at government level where it is stated that they have the same attention rights, I mean, as everyone else. Being homosexual does not mean that attention will be different or everyone get the same attention" [Interview 13, Nurse (woman)]

\subsection{LGBT Population}

\subsubsection{Characteristics of LGBT Population}

LGBT participants mentioned that their population is diverse. There are people with different sexual orientation in all scenarios: social, political, economic and cultural. In the same manner, health service providers mentioned that the only difference between them and heterosexuals is sexual orientation. It is important to highlight that LGBT identifies discrimination and the sociopolitical process undergone to counteract it. They also identified 
that between younger LGBT there is greater endogenous discrimination accentuated by differences in their socioeconomic levels, gender identity and personal or collective tastes.

“...Well, there are too many. There are teachers at this university, city managers, congressmen in this country that are surely LGBT, as well as recyclers and homeless" [Interview 22 gay man]

"Socioculturally, the LGBT community is broadly accepted though there is still discrimination within them. Currently the youngest are split in family-like structures and use the same last name, using it to exclude or fight"

[Interview 33, gay man]

3.2.2 Quality of Life (QOL), Health Related Quality of Life (HRQOL), Oral Health Related Quality of Life (OHRQOL)

LGBT defined QOL as the valuation and respect from society towards oneself, guaranteeing the development of the individual. Furthermore, they agree with providers in that QOL is linked to the guarantee of access and enjoyment of basic goods and services.

"It is leading a healthy life, a full life, a life filled with obstacles so I feel good before anyone, before society. It is to be respected in regards to gender: feminine, masculine, and independent"

[Interview 35, transgender woman]

"...I consider that quality of life is having health first and foremost, having the tools to adequately live with my needs. Regardless if you are rich, poor or have enough to have a comfortable life, but having enough" [Interview 37, gay man]

The concept of HRQOL was described by providers as the provision of a human health service: timely, effectively, efficiently and comprehensively.

“...that I am seen on time. That I am treated nicely, not rushing. There are many doctors that check you without taking their time or looking at you. They should be nice, check you and care for the patients"

[Interview 33, gay man]

When interviewing LGBT on OHRQOL, they expressed it is the health of the mouth and the image projected to others.

“...in one simple word: being clean. Not having oral diseases as cavities. That teeth look good..., as mentioned before, to me it is a state of wellbeing. If I don't feel comfortable with someone else because of my teeth, then I won't have oral quality of life" [Interview 28 , gay man]

\subsubsection{Discrimination as a Concept and Experiences}

LGBT population explains discrimination as the act of being treated differently because of a specific condition. It feels identified with the discrimination process because of their different sexual orientation. Some groups as transsexual and transgender express having lived discriminative experiences in public spaces in the city.

"To me discrimination is being treated as a different entity, I mean, as a freak..."

[Interview 28, homosexual man]

“...because of the way you walk, dress, speak, the more delicate manners. It is most seen at school but people always look at you weird when you go out" [Interview 35, transgender woman]

\subsubsection{LGBT Population Access to Health Services}

LGBT population expresses being comfortable with public and private health services. They do not correlate perceiving discriminating attitudes given their sexual orientation or gender identity. However, they do identify structural flows in the public system, as the limitation of appointment time, lack of insurance benefits in dental procedures and dehumanization of health.

"I have counted the minutes, seconds and scarce seconds of each appointment. It is the same for children, elders, homeless or poor people, and myself. My appointment is as long to the minutes and seconds" [Interview 24, transgender woman]

"Some dentists don't care. For rushing they do not prescribe as needed. I think that as dentists they should concern themselves with oral wellbeing. Sometimes you feel the dentist just looked at the teeth and says: you are ok, or there is nothing wrong, or floss more, or just leave... Not being seen on time is a structural norm in the system" [Interview 27, gay man] 


\subsubsection{Proposals and Strategies}

Proposals and strategies to reduce discrimination based on sexual diversity brought forward by LGBT groups is based on education from early stages focusing on values as respect, tolerance, solidarity and coexistence.

“...starting from social education, I mean, people first have to understand the LGBT community and what are its particularities, in order to accept it. Hence, the first step would be to socially educate people” [Interview 23, bisexual woman]

\section{Discussion}

It was found that some LGBT groups have experienced experiences of discrimination in health services and other social scenarios. This has a negative impact on their quality of life hampering fundamental human rights. Such events are more common for transsexuals whose physical appearance causes greater visual impact on other citizens. The health providers perceived discriminatory behaviors by their counterparts and this situation is more common in public health centers than private dental offices. Notwithstanding, some LGBT do not notice discriminatory behavior at the dentist from the medical staff.

Studies aimed at making a characterization of LGBT make an important collectivity because of social movements and political developments (Martel, 2014; Prado, Mountian, Machado, \& Santos, 2010). In Colombia, particularly, the socio political configuration of this group began in the 40 s from anonymity, while becoming a strong movement in the 80s and evolving until recently (Maduro Santamaría, 2009). Generally speaking, it is constituted as a diverse group in regards to social and educational levels, political position, and ethnic background and believes (Barrientos-Delgado, Cárdenas-Castro, \& Gómez-Ojeda, 2014). The results of the research considered a category that describes the main characteristics of the group, from their own perceptions, how they see themselves and their social group, as well as how professionals perceive the LGBT population.

In regards to discriminatory experiences and their concepts and perceptions of this social phenomenon, results match other studies that describe different moments of discrimination in social and work environments (Barrientos, Silva, Catalan, Gomez, \& Longueira, 2010; Kass, Faden, Fox, \& Dudley, 1992). This study showed that the conceptual construction regarding discrimination developed by service providers as well as LGBT agrees with social epidemiology approaches by Krieger $(1999,2001)$, even with some differences from the analysis of those involved. LGBT is described as a group that lives a sociocultural process of exogenous discrimination (non homosexuals) as well as endogenous (people with the same sexual orientation).

Even though research on discrimination against LGBT in oral health services is scarce, some studies show how providers and the group can perceive discrimination in health (Kass et al., 1992). In California, for example, a study reported that $18.7 \%$ of doctors felt uncomfortable when providing services to homosexuals, particularly those with HIV (Smith \& Mathews, 2007). In regards to access of transsexual population in Spain, in a study by Esteva de Antonio et al. (2012), the main results are the fact that there is not a homogeneous provision in the Autonomous Communities, or direct support from governmental entities. Even if not a generalization, some discourses refers certain resistance and opposition to attention of transsexuals, mainly due to ideology. Campo Díaz y Herazo (2008), showed a bibliographic review of homophobia in dentistry students and hygienist. It concluded that the levels of homophobia are low. This research found behaviors towards LGBT identified by the health personnel though not perceived by LGBT patients, which interfere with a comprehensive health service and were accentuated by visual impact caused and in the public system. These can be attributed to personal beliefs and the structure of the public system, acting as barriers to access, as found by other studies (Kass et al., 1992).

Quality of life has been studied by different disciplines and for diverse social groups, by applying both quantitative and qualitative methodologies. However, research relates that QOL, HRQOL and OHRQOL in LGBT population are less frequent. Barrientos y Cárdenas (2013) analyzed the effects of prejudice in the quality of life of gay and lesbians, finding that having homophobic experiences can generate negative effects on QOL of sexual minorities. It is also mentioned that LGBT has an elevated tendency to be victims of violence due to sexual orientation and are more prone to suffering psychiatric disorders as depression and alcoholism than heterosexuals. As expressed by the participants, those conditions have a negative impact on the quality of life in the light of the subjective perception of wellbeing by psychologically, socially and economically affecting the LGBT individual. These do not allow them to develop their potential by hindering the access to goods, services and opportunities in equal terms.

An important finding has to do with policies and strategies to prevent and diminish discrimination as expressed 
by participants. The anti-discrimination lay is implicit in the Universal Declaration of Human Rights (United Nations, 1948) which has been followed by different law initiatives in different countries to promote equity and equality of rights of all people. This requires the creation of policies and strategies to diminish discrimination levels, including discrimination due to sexual orientation (Lerner, 2003; Martel, 2014). In Colombia, particularly, Law 1482 of 30th November of 2011, which modifies the criminal code, in its article 1 declares as an objective to guarantee the protection of rights of a person, a group of people, a community or town, as they be violated through acts of racism and discrimination (Colombia. Congreso de la República, 2011). This is considered advancement within Colombian jurisprudence to guarantee the free exercise of human rights. It is implicit that the Law, together with international treaties on human rights, permeates all areas of social development, including the health sector where attention, diagnosis, treatment and counseling to every person are guaranteed without possibility of discrimination.

As strength of this research it is important to mention the qualitative perspective which allows approaching social realities from the actors and their different perspectives. Also, it is important to highlight the innovative nature of the study, even internationally, allowing a broader approach. In contrast, the narrow view of oral health service providers regarding discrimination is a real limitation, therefore it is important to include different providers in like studies. According to the discourses of participants and the type of phenomenological analysis conducted it is very difficult to distinguish what is related to the LGBT fact and what is not. For example, the overreaction to an HIV patient (hygiene measures, etc.) is linked to the disease, not to the patient's sexual preference but interviewed participants expressed ideas of discrimination in several spaces and they attributed some procedures as discriminatory. Similarly, qualitative research acknowledges a changing and dynamic social reality allowing new research to complete the participant's discourses through demographic studies that allow the characterization of the phenomenon in public and private institutions in Medellín, with the support of organizations for sexual diversity. Participative research should allow the generation of new strategies for social inclusion.

\section{Conclusion}

LGBT population is vulnerable to perceive some experiences of discrimination of health services and in other social scenes, having a negative impact on their quality of life. Political actions and strategies could contribute to diminish inequality and inequity situations in LGBT groups from a public health perspective.

\section{Funding}

This work was supported exclusively by the authors, without external sponsorship.

\section{Competing Interests Statement}

The authors declare that there is no conflict of interests regarding the publication of this paper.

\section{References}

Barrientos, J., \& Cárdenas, M. (2013). Homofobia y calidad de vida de gay y lesbianas: Una mirada psicosocial. Homophobia and Quality of Life in Gay Men and Lesbians: A Psychosocial View. Psykhe (Santiago), 22(1), 3-14. http://dx.doi.org/10.7764/psykhe.22.1.553

Barrientos, J., Silva, J., Catalan, S., Gomez, F., \& Longueira, J. (2010). Discrimination and victimization: Parade for lesbian, gay, bisexual, and transgender (LGBT) pride, in Chile. J Homosex, 57(6), 760-775. http://dx.doi.org/10.1080/00918369.2010.485880

Barrientos-Delgado, J., Cárdenas-Castro, M., \& Gómez-Ojeda, F. (2014). Características sociodemográficas, bienestar subjetivo y homofobia en una muestra de hombre's gay en tres ciudades chilenas. Socio-demographic characteristics, subjective well-being, and homophobia experienced by a sample of gay men from three cities in Chile. Cad. Saúde Pública, 30(6), 1259-1269. http://dx.doi.org/10.1590/ 0102-311X00108413

Bhui, K., Stansfeld, S., McKenzie, K., Karlsen, S., Nazroo, J., \& Weich, S. (2005). Racial/ethnic discrimination and common mental disorders among workers: Findings from the EMPIRIC Study of Ethnic Minority Groups in the United Kingdom. Am J Public Health, 95(3), 496-501. http://dx.doi.org/10.2105/AJPH. 2003.033274

Burgess, D., Lee, R., Tran, A., \& van Ryn, M. (2008). Effects of perceived discrimination on mental health and mental health services utilization among gay, lesbian, bisexual and transgender persons. J LGBT Health Res, 3(4), 1-14. http://dx.doi.org/10.1080/15574090802226626

Campo, A., Díaz, A. J., \& Herazo, E. (2008). Homofobia en estudiantes de odontología e higiene oral: Revisión 
sistemática de la última década. Homophobia among dental and dental hygiene students: A systematic review of the last decade. Rev CES Odont, 21(2), 63-68.

Colombia. Congreso de la República. (2011). Ley 1482 de 30 de Noviembre de 2011. Por medio de la cual se modifica el Código Penal y se establecen otras disposiciones. Law 1482 of November 30, 2011. This Law amends the Criminal Code and other provisions are set. Bogotá: Congreso de la República. Diario Oficial 48270.

de Antonio, I. E., Gómez-Gil, E., Almaraz, M. C., Martínez-Tudela, J., Bergero, T., Olveira, G., ... Gidseen, G. (2012). Organización de la asistencia a la transexualidad en el sistema sanitario público español. Organization of healthcare for transsexual persons in the Spanish national health system. Gac Sanit, 26(3), 203-209. http://dx.doi.org/10.1016/j.gaceta.2011.10.021

Gee, G. C., Ryan, A., Laflamme, D. J., \& Holt, J. (2006). Self-reported discrimination and mental health status among African descendants, Mexican Americans, and other Latinos in the New Hampshire REACH 2010 Initiative: The added dimension of immigration. Am J Public Health, 96(10), 1821-1828. http://dx.doi.org/ 10.2105/AJPH.2005.080085

Gee, G. C., Spencer, M. S., Chen, J., \& Takeuchi, D. (2007). A nationwide study of discrimination and chronic health conditions among Asian Americans. Am J Public Health, 97(7), 1275-1282. http://dx.doi.org/ 10.2105/AJPH.2006.091827

Johnson, C. V., Mimiaga, M. J., \& Bradford, J. (2008). Health care issues among lesbian, gay, bisexual, transgender and intersex (LGBTI) populations in the United States: Introduction. J Homosex, 54(3), 213-224. http://dx.doi.org/10.1080/00918360801982025

Kass, N. E., Faden, R. R., Fox, R., \& Dudley, J. (1992). Homosexual and bisexual men's perceptions of discrimination in health services. Am J Public Health, 82(9), 1277-1279. http://dx.doi.org/10.2105/AJPH.82. 9.1277

Keck, T. (2009). Beyond Backlash: Assessing the Impact of Judicial Decisions on LGBT Rights. Law Soc Rev, 43(1), 151-186. http://dx.doi.org/10.1111/j.1540-5893.2009.00370.x

Krieger, N. (1999). Embodying inequality: A review of concepts, measures, and methods for studying health consequences of discrimination. Int $J$ Health Serv, 29(2), 295-352. http://dx.doi.org/10.2190/M11WVWXE-KQM9-G97Q

Krieger, N. (2001). A glossary for social epidemiology. J Epidemiol Community Health, 55(10), 693-700. http://dx.doi.org/10.1136/jech.55.10.693

Krieger, N., Rowley, D. L., Herman, A. A., Avery, B., \& Phillips, M. T. (1993). Racism, sexism, and social class: Implications for studies of health, disease, and well-being. Am J Prev Med, 9(6 Suppl), 82-122.

Larson, A., Gillies, M., Howard, P. J., \& Coffin, J. (2007). It's enough to make you sick: The impact of racism on the health of Aboriginal Australians. Aust N Z J Public Health, 31(4), 322-329. http://dx.doi.org/10.1111/ j.1753-6405.2007.00079.x

Lauderdale, D. S., Wen, M., Jacobs, E. A., \& Kandula, N. R. (2006). Immigrant perceptions of discrimination in health care: The California Health Interview Survey 2003. Med Care, 44(10), 914-920. http://dx.doi.org/ 10.1097/01.mlr.0000220829.87073.f7

Lerner, N. (2003). Group rights and discrimination in international law (Vol. 77). The Hague: Martinus Nijhoff Publishers.

Maduro Santamaría, B. M. (2009). Participación politica de la población LGBT de Bogotá entre los años 2004-2007. Political participation of LGBT population of Bogota between 2004-2007. Maestría en Estudios Políticos, Pontificia Universidad Javeriana, Bogotá.

Martel, F. M. (2014). Global Gay: Cómo la revolución gay está cambiando el mundo. Global Gay: How gay culture is changing the world. Translation of Petit Fontseré, N. Buenos Aires: Aguilar, Altea, Taurus, Alfaguara.

Mays, V. M., \& Cochran, S. D. (2001). Mental health correlates of perceived discrimination among lesbian, gay, and bisexual adults in the United States. Am J Public Health, 91(11), 1869-1876. http://dx.doi.org/10. 2105/AJPH.91.11.1869

Mustanski, B. S., Garofalo, R., \& Emerson, E. M. (2010). Mental health disorders, psychological distress, and suicidality in a diverse sample of lesbian, gay, bisexual, and transgender youths. Am J Public Health, 
100(12), 2426-2432. http://dx.doi.org/10.2105/AJPH.2009.178319

Pachter, L. M., \& Coll, C. G. (2009). Racism and child health: A review of the literature and future directions. $J$ Dev Behav Pediatr, 30(3), 255-263. http://dx.doi.org/10.1097/DBP.0b013e3181a7ed5a

Paradies, Y. (2006). A systematic review of empirical research on self-reported racism and health. Int $J$ Epidemiol, 35(4), 888-901. http://dx.doi.org/10.1093/ije/dyl056

Pascoe, E. A., \& Smart Richman, L. (2009). Perceived discrimination and health: A meta-analytic review. Psychol Bull, 135(4), 531-554. http://dx.doi.org/10.1037/a0016059

Prado, M. A. M., Mountian, I., Machado, F., \& Santos, L. (2010). Los movimientos LGTB y la lucha por la democratización de las jerarquias sexuales en Brasil. LGBT movements and the struggle for the democratization of sexual hierarchies in Brazil. Revista Digital Universitaria, 11(7), 1-15.

Quijano, A. A., \& Albarracín, M. (2009). Activismo judicial y derechos de los LGTB en Colombia: Sentencias emblemáticas. Judicial activism and legal rights of LGBT in Colombia: emblematic statements: Instituto Latinoamericano de Servicios Legales Alternativos (ILSA).

Quinn, G., Degener, T., \& Bruce, A. (2002). Human rights and disability: The current use and future potential of United Nations human rights instruments in the context of disability. United Nations Publications.

República de Colombia. Ministerio de Salud y Protección Social. (1993). Resolución no 008430 de 1993 (4 de octubre de 1993). Por la cual se establecen las normas científicas, técnicas y administrativas para la investigación en salud Resolution No. 008430/1993 (October 4th, 1993). Scientific, technical and administrative for health research standards are established. Bogotá: Ministerio de Salud y Protección Social.

Ronai, C. R., Zsembik, B. A., \& Feagin, J. R. (2014). Everyday sexism in the third millennium. Routledge.

Smith, D. M., \& Mathews, W. C. (2007). Physicians' attitudes toward homosexuality and HIV: Survey of a California Medical Society-revisited (PATHH-II). J Homosex, 52(3-4), 1-9. http://dx.doi.org/10.1300 /J082v52n03_01

United Nations. (1948). The Universal Declaration of Human Rights. Retrieved from http://www.un. org/en/documents/udhr/

Vargas Melgarejo, L. M. (1994). Sobre el concepto de percepción. About the concept of perception. Alteridades, $4(8), 47-53$.

World Health Organisation (WHO). (2007). A conceptual framework for action on social determinants of health. Retrieved from http://www.who.int/social_determinants/resources/csdh_framework_action_05_07.pdf

World Medical Association General Assembly. (2004). World Medical Association Declaration of Helsinki: Ethical principles for medical research involving human subjects. J Int Bioethique, 15(1), 124-129.

Zichi Cohen, M., et al. (1994). Schools of Phenomenology: Implications for Research. In J. Morse (Ed.), Critical Issues in Qualitative Research Methods. Thousand Oaks: Sage Publications.

\section{Copyrights}

Copyright for this article is retained by the author(s), with first publication rights granted to the journal.

This is an open-access article distributed under the terms and conditions of the Creative Commons Attribution license (http://creativecommons.org/licenses/by/3.0/). 